\title{
Isolation and characterization of Leydig cells from adult bonnet monkeys (Macaca radiata): evidence for low steroidogenic capacity in monkey Leydig cells in contrast to rat Leydig cells
}

\author{
M Anbalagan, V Sriraman ${ }^{\mathbf{1}}$ and A Jagannadha Rao \\ Department of Biochemistry, Indian Institute of Science, Bangalore 560 012, India \\ ${ }^{1}$ Department of Molecular and Cellular Biology, Baylor College of Medicine, Houston, Texas 77030, USA \\ (Requests for offprints should be addressed to A Jagannadha Rao; Email: ajrao@biochem.iisc.ernet.in)
}

\begin{abstract}
Most of the available information on Leydig cells has been obtained using a rodent model system. With an objective to extend the observations made with rat Leydig cells (RLCs) to primates, a method has been developed to isolate Leydig cells from monkey (Macaca radiata) testis. Enzymatic dissociation of monkey testis followed by Percoll-gradient fractionation of the interstitial cells resulted in the recovery of Leydig cells at densities corresponding to $1.064-1.070 \mathrm{~g} / \mathrm{ml}$. Purified (90-94\%) monkey Leydig cells (MLCs) stained positive for the Leydig cell marker $3 \beta$-hydroxysteroid dehydrogenase.
\end{abstract}

The cells responded to in vitro addition of human chorionic gonadotropin (hCG) and produced testosterone. Comparison of the in vitro testosterone-producing ability of MLCs with RLCs revealed that MLCs have much less steroidogenic capacity compared with the RLCs. Analysis revealed that limitation in substrate availability to mitochondrial $\mathrm{P}_{450}$ side chain cleavage enzyme and low mitochondrial and smooth endoplasmic reticulum content in MLCs could be the possible reasons for the low steroidogenic capacity of the MLCs.

Journal of Endocrinology (2003) 179, 175-182

\section{Introduction}

Leydig cells are the site of synthesis and secretion of testosterone, the major male sex hormone essential for the normal functioning of the male reproductive system (Sachs \& Meisel 1988). The available information on Leydig cell development and regulation of steroidogenesis is mostly based on studies using rodent model systems. Often it is not possible to extrapolate the observations made in the rodent model system to humans. Due to obvious ethical reasons and problems in carrying out similar studies in humans, non-human primate models have been widely used.

Considerable differences exist in the morphology and physiology of Leydig cells across species. The organization of Leydig cells in the monkey testis differs from that in the rat testis. In the rat, the Leydig cells appear to be organized in continuous strings and the endothelium of lymphatics is lacking. In the monkey testis, the Leydig cells are scattered with abundant loose connective tissue between the seminiferous tubules, and centrally placed well-defined lymphatic vessels can be observed. The interstitial space is not continuous in the monkey testis unlike the situation in the rat (Fawcett et al. 1973). Ultrastructural and histochemical studies of post natal Leydig cell development in the marmoset monkey (Callithrix jacchus) testis revealed that three different Leydig cell types namely neonatal, immature and adult Leydig cells are present in the testis (Rune et al. 1991). Inhibition of the hypothalamopituitary-testicular (HPT) axis of marmoset monkeys by the administration of a gonadotropin-releasing hormone antagonist (antide) from birth for 7 weeks resulted in drastic changes in the Leydig cells. The cells were atropic and exhibited very irregular nuclei and the organelles involved in steroid synthesis were reduced to the extent of being barely evident (Prince et al. 1998). Thus it appears that, as in rodents, gonadotropic hormones are the primary regulators of postnatal Leydig cell development in primates. The receptors for androgen and estrogen (both $\alpha$ and $\beta$ ) have also been localized in Leydig cells of monkey testis by immunohistochemistry (Fisher et al. 1997, Pelletier 2000, Saunders et al. 2001) suggesting that similar regulatory mechanisms may operate in monkey Leydig cells (MLCs) as in the case of rodents. Testosterone can be derived from pregnenolone either by $\Delta^{4}$ or $\Delta^{5}$ pathways. Studies carried out with Cebus monkey testis slices (Rey et al. 1995) suggest that the $\Delta^{5}$ pathway predominates in MLCs in contrast to rat Leydig cells (RLCs).

The above cited limited information available on MLCs is mainly based on studies carried out with histological sections or tissue slices of testis. Considering the 
heterogeneity of the cell types present in the testes, it will be more appropriate to use purified Leydig cells to study the effect of different hormones and growth factors on Leydig cell function - this will certainly provide more reliable information. In the absence of a published protocol to isolate Leydig cells from monkey testis, the present study was undertaken to develop a method to isolate homogeneous populations of Leydig cells from the monkey testis (Macaca radiata). Also, since the in vitro testosteroneproducing ability of MLCs was found to be quite low compared with RLCs, a study has been carried out to ascertain the possible reasons for the low steroidogenic activity of MLCs.

\section{Materials and Methods}

\section{Animals}

Adult male bonnet monkeys (6-10 years old) housed at the Primate Research Laboratory, Indian Institute of Science, Bangalore, India, were used in this study. Only those monkeys which exhibited the characteristic nocturnal surge in serum testosterone levels were recruited in this study (Mukku et al. 1976). Ninety-day-old adult Wistar rats were obtained from the Central Animal Facility (CAF), Indian Institute of Science, Bangalore, India. Animals were fed with pelleted feed procured from Mysore Snack Feeds, Bangalore, India. The animals were maintained under standard conditions (12-h light, 12-h darkness schedule, with water and pelleted food available ad libitum). Animal procedures employed in this study were cleared by the Institutional Animal Ethical Committee. Unilateral castration was carried out in the untreated monkeys, which were used to investigate the role of estrogen in the regulation of maturation of epididymal sperm.

\section{Isolation of Leydig cells from monkey testis}

Monkeys were anesthetized with ketamine $(10 \mathrm{mg} / \mathrm{kg}$ body weight) and following unilateral castration the testis was processed for Leydig cell isolation. In order to decrease blood cell contamination, ice-cold medium was perfused through the testis blood capillaries. (Medium refers to Dulbecco's modified Eagle's medium/Ham F12 with HEPES and without phenol red 1 1/pkg (Sigma) dissolved in 1 litre double distilled water supplemented with $1.2 \mathrm{~g}$ sodium bicarbonate, $1 \mathrm{~g}$ bovine serum albumin (Sigma) and $30 \mathrm{mg}$ soya bean trypsin inhibitor (Worthington Biochemical Corporation, Lakewood, NJ, USA); $\mathrm{pH}$ was adjusted to $7 \cdot 4$ ). After making sure that as much blood as possible was drained out, the outer tunica was removed and the tissue was subjected to enzymatic digestion by the procedures described below. The following procedures were evaluated to ascertain the purity, yield of Leydig cells and in vitro response to the addition of human chorionic gonadotropin (hCG).
Procedure 1 The testis tissue was minced and subjected to digestion in a $50 \mathrm{ml}$ falcon tube containing 2500 units collagenase type 3 (Worthington Biochemical Corporation) and 750 units DNase (Worthington Biochemical Corporation) in $10 \mathrm{ml}$ medium. The tubes were kept half immersed in a shaking water bath with constant agitation (50 times/min) at $34{ }^{\circ} \mathrm{C}$ for $30 \mathrm{~min}$. The enzymatic activity was terminated by the addition of excess medium. The tubules were allowed to settle by gravity and the medium consisting of interstitial cells was aspirated and filtered through a $100 \mu \mathrm{m}$ nylon mesh. The filtrate was centrifuged at $250 \mathrm{~g}$ for $10 \mathrm{~min}$ at $25^{\circ} \mathrm{C}$, which yielded a crude interstitial pellet.

Procedure 2 The testis tissue was cut into pieces each weighing approximately $500 \mathrm{mg}$. Four testis pieces were taken in $50 \mathrm{ml}$ falcon tubes and subjected to enzymatic digestion in $10 \mathrm{ml}$ medium containing 700 units collagenase, 750 units DNase and 1.5 units dispase type 1 (Roche Biochemicals, Penzberg, Germany). The tubes were half immersed in a shaking water bath with constant agitation $(50$ times $/ \mathrm{min})$ at $34^{\circ} \mathrm{C}$. Digestion was carried out until the tubules were dispersed (approximately 40-45 $\mathrm{min}$ ) and the enzyme action was terminated by adding excess medium. The interstitial cells were separated from the tubules as mentioned in procedure 1.

The interstitial cell pellet obtained by the procedures

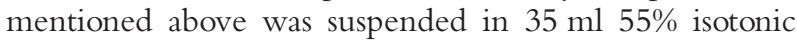
Percoll with 750 units DNase in Oakridge tubes. The tubes were centrifuged at $20000 \mathrm{~g}$ in a JA-20 rotor (Beckman, UK) for $1 \mathrm{~h}$ at $4{ }^{\circ} \mathrm{C}$. Ignoring the first $3 \mathrm{ml}$ of the gradient (which contained cell debris), and the last $4 \mathrm{ml}$ which contained red blood corpuscles (RBCs), $4 \mathrm{ml}$ fractions of the middle layer were collected and the cells present in the Percoll fractions were pelleted down by centrifugation at $250 \mathrm{~g}$ for $10 \mathrm{~min}$ at $25^{\circ} \mathrm{C}$ after diluting with 3-4 volumes of the medium.

Equal number of cells $\left(1 \times 10^{5}\right.$ cells $)$ present in the different fractions of Percoll gradient were incubated with or without 100 ng hCG (a kind gift from Dr A F Parlow, National Hormone and Pituitary Program, NIDDK, USA) in $1.75 \mathrm{ml}$ microfuge tubes containing $500 \mu \mathrm{l}$ medium. The tubes were incubated for $4 \mathrm{~h}$ in a shaking water bath at $34{ }^{\circ} \mathrm{C}$ with constant agitation after which the tubes were spun at $250 \mathrm{~g}$ for $10 \mathrm{~min}$ at $4{ }^{\circ} \mathrm{C}$; the supernatant was frozen at $-20^{\circ} \mathrm{C}$ until testosterone in $100 \mu \mathrm{l}$ of the medium was estimated by a sensitive RIA standardized in our laboratory (Sriraman et al. 2000).

Using both the procedures described above, Leydig cell isolation was carried out simultaneously six times with six different monkey's testes and it was consistently found that MLCs could be recovered at densities corresponding to $1 \cdot 064-1 \cdot 070 \mathrm{~g} / \mathrm{ml}$. The purity of MLCs was assessed by $3 \beta$-hydroxysteroid dehydrogenase (3ß-HSD) staining (Klinefelter et al. 1987) and the viability of the cells was tested by Trypan Blue dye exclusion test (Phillips 1973). 
Considering the Leydig cell purity, the second procedure was adopted for isolation of Leydig cells from monkey testis to compare the steroidogenic capacity of monkey and rat Leydig cells.

\section{Isolation of Leydig cells from adult rats}

Adult Leydig cells up to a purity of 90-95\% were isolated from 90-day-old rats according to the procedure of Sriraman et al. (2000, 2003) which is a modification of the procedure described by Klinefelter et al. (1987). The decapsulated testis was subjected to collagenase digestion in a $50 \mathrm{ml}$ plastic tube containing $10 \mathrm{ml}$ medium with collagenase (600 units) and DNase (750 units). The tubes were placed in a shaking water bath with constant agitation (50 times $/ \mathrm{min}$ ) at $34{ }^{\circ} \mathrm{C}$ for $15-20 \mathrm{~min}$ until the tubules were separated. The enzyme action was terminated by adding excess medium. The tubules were allowed to settle by gravity and the medium, consisting of interstitial cells, was aspirated and filtered through a $100 \mu \mathrm{m}$ nylon mesh. The filtrate was centrifuged at $250 \mathrm{~g}$ for $10 \mathrm{~min}$ at $25^{\circ} \mathrm{C}$, which yielded a crude interstitial pellet. The pellet obtained was suspended in $35 \mathrm{ml} 55 \%$ isotonic Percoll with 750 units DNase in Oakridge tubes. The tubes were centrifuged at $20000 \mathrm{~g}$ in a JA-20 rotor (Beckman, UK) for $1 \mathrm{~h}$ at $4{ }^{\circ} \mathrm{C}$. Percoll fractions corresponding to densities of $1 \cdot 070-1 \cdot 090 \mathrm{~g} / \mathrm{ml}$ were collected and the cells present in this fraction were pelleted down by centrifugation at $250 \mathrm{~g}$ for $10 \mathrm{~min}$ at $25^{\circ} \mathrm{C}$ after diluting with 3-4 volumes of medium.

\section{Comparison of in vitro testosterone production by rat and monkey Leydig cells}

Monkey and rat Leydig cells were isolated simultaneously and incubated in $1.7 \mathrm{ml}$ microfuge tubes to assess their in vitro testosterone-producing capacity. One hundred thousand $\left(1 \times 10^{5}\right)$ Leydig cells were suspended in $500 \mu \mathrm{l}$ medium with or without different modulators (100 ng hCG, $20 \mu \mathrm{M}$ forskolin or $20 \mu \mathrm{M} 22-\mathrm{R}-\mathrm{OH}$-cholesterol) and incubated in a shaking water bath at $34{ }^{\circ} \mathrm{C}$ for $4 \mathrm{~h}$ with constant agitation. At the end of the incubation, the tubes were spun at $250 \mathrm{~g}$ for $10 \mathrm{~min}$ at $4{ }^{\circ} \mathrm{C}$ and the supernatant was stored at $-20^{\circ} \mathrm{C}$ until processed for testosterone estimation by RIA.

\section{Staining of testis sections with $\mathrm{DiOC}_{6}(3)$}

The procedure for staining was as described by Terasaki (1998). Rat testis was fixed in $0.5 \%$ glutaraldehyde (Sigma) in $100 \mathrm{mM}$ cacodylate buffer and $10 \mu \mathrm{m}$ frozen sections were cut using a cryostat. The sections on the glass slides were incubated for $5 \mathrm{~min}$ with the fluorescent dye 3,3'-dihexyloxacarbocyanine iodide $\left(\mathrm{DiOC}_{6}(3)\right)$ (Molecular Probes Oregon, USA) $(0.5 \mu \mathrm{g} / \mathrm{ml}$ in $100 \mathrm{mM}$ cacodylate buffer), which is used for staining endoplasmic reticulum and mitochondria. Later, these sections were mounted using a glass cover-slip with a photo bleaching reduction reagent, n-propyl gallate $(1 \mathrm{mg} / \mathrm{ml}$ in a solution of $90 \%$ glycerol and 10\% PBS), observed under a fluorescent microscope with blue light excitation and the green fluorescent image was captured (LEICA fluorescence microscope, Germany).

\section{Staining of RLCs and MLCs with $\mathrm{DiOC}_{6}(3)$}

Rat and monkey Leydig cells were isolated simultaneously, and were cultured on glass cover-slips submerged in the culture medium for $6 \mathrm{~h}$, following which the cells attached to the cover-slips were incubated for $5 \mathrm{~min}$ with medium containing $2.5 \mu \mathrm{g} / \mathrm{ml} \mathrm{DiOC}(3)$. Later, the excess dye was washed with dye-free medium and the cover-slips were mounted on a glass slide with a photo bleaching reduction reagent, n-propyl gallate $(1 \mathrm{mg} / \mathrm{ml}$ in a solution of $90 \%$ glycerol and $10 \%$ PBS), observed under fluorescent microscope with blue light excitation and the green fluorescent image was captured. The fluorescence emitted per unit area of cytoplasm of 10-15 monkey and rat Leydig cells was analyzed by computer using Image Pro-Plus image analysis software (Media Cybernetics, Inc., Silver Spring, MD, USA).

\section{Statistical analysis}

The data are presented as means \pm S.E. of at least three separate experiments performed with the same protocol. The data were analyzed by Kruskal-Wallis ANOVA followed by Neuman-Keuls test employing Graphpad software (San Diego, CA, USA) to determine significant differences in the group, and a $P$ value less than 0.05 was considered to be statistically significant.

\section{Results}

\section{Leydig cell isolation from adult bonnet monkeys}

Enzymatic digestion of monkey testis released interstitial cells along with the germ cells, sperm and RBCs. Following Percoll gradient fractionation of the interstitial cells, assessment of in vitro testosterone production by the cells in various fractions revealed that the cells recovered in fractions corresponding to densities of $1.064-1.070 \mathrm{~g} / \mathrm{ml}$ produced maximum testosterone with or without hCG $\left(5 \cdot 14 \pm 1 \cdot 01 \mathrm{ng}\right.$ testosterone $/ 10^{6}$ cells (mean \pm S.E.) without hCG and $23.63 \pm 3.8 \mathrm{ng}$ testosterone $/ 10^{6}$ cells (mean \pm S.E.) with hCG) (Fig. 1). The values represent testosterone produced by MLCs obtained by the second procedure.

Of the two different procedures employed for enzymatic dissociation of monkey testis, the yield of MLCs obtained by procedure 1 was $7-10 \times 10^{5}$ cells $/ g$ tissue 


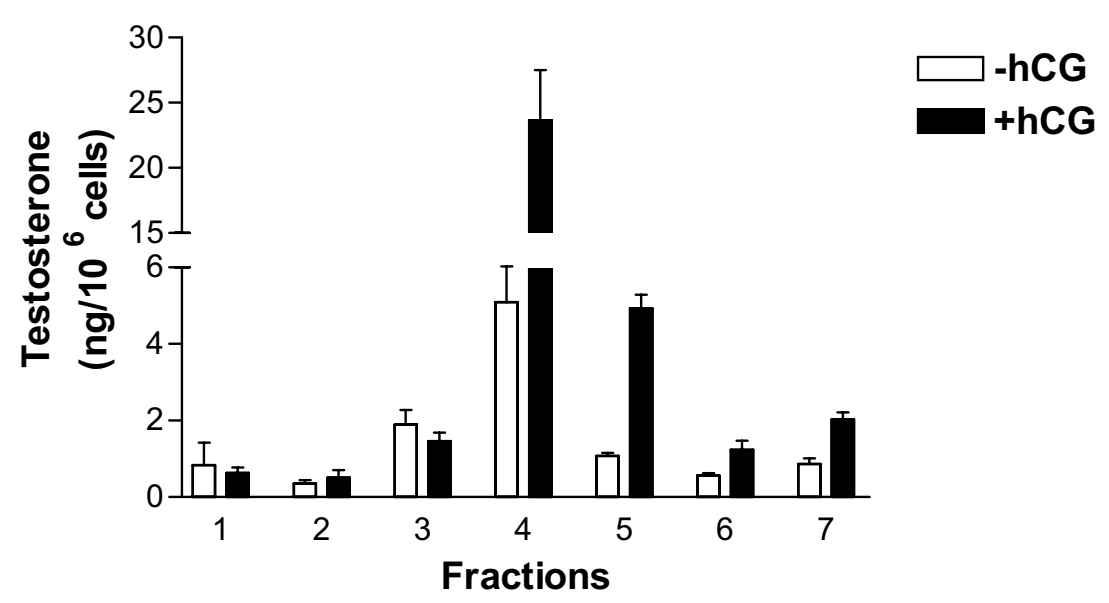

Figure 1 Graphical representation of testosterone produced by monkey testis interstitial cells present in various fractions from Percoll gradient fractionation. Equal numbers of cells $\left(1 \times 10^{5}\right)$ present in different fractions were incubated in triplicate with or without $100 \mathrm{ng}$ hCG in $500 \mu \mathrm{l}$ medium at $34{ }^{\circ} \mathrm{C}$ for $4 \mathrm{~h}$ in a shaking water bath with constant agitation.

The testosterone in the medium was estimated by RIA. Values represent means \pm S.E. $n=6$.

with $85-90 \%$ purity, as assessed by $3 \beta-$ HSD staining. However, by following the second procedure, $5-7 \times 10^{5}$ cells/g tissue were obtained with $90-96 \%$ purity (Fig. 2). There was no significant difference in the in vitro hCGstimulated testosterone production by the Leydig cells obtained by either of the procedures. More than $90 \%$ of cells were viable in both the procedures as assessed by the Trypan Blue dye exclusion test.

Comparison of in vitro testosterone production by MLCs and RLCs in the presence of various modulators

Rat and monkey Leydig cells were isolated simultaneously and in vitro testosterone production by these cells was monitored in the presence of various modulators. Control RLCs produced $8 \cdot 33 \pm 1 \cdot 04 \mathrm{ng}$ testosterone $/ 10^{6}$ cells (mean \pm S.E.) and MLCs produced $4 \cdot 20 \pm 1 \cdot 24 \mathrm{ng}$ testosterone $/ 10^{6}$ cells (mean \pm S.E.). In the presence of hCG, RLCs produced 137.46 $\pm 6 \cdot 66$ ng testosterone $/ 10^{6}$ cells (mean \pm S.E.) (a 16.5-fold increase in testosterone production over the control). However, under identical conditions, MLCs produced only $19 \cdot 66 \pm 4 \cdot 17 \mathrm{ng}$ testosterone $/ 10^{6}$ cells (mean \pm S.E.) (a $4 \cdot 6$-fold increase in testosterone production over the control) (Fig. 3).

It is known that cAMP produced by adenylate cyclase is the second messenger mediating the action of luteinizing hormone (LH) on Leydig cell testosterone production. In order to rule out the possibility that the observed relatively

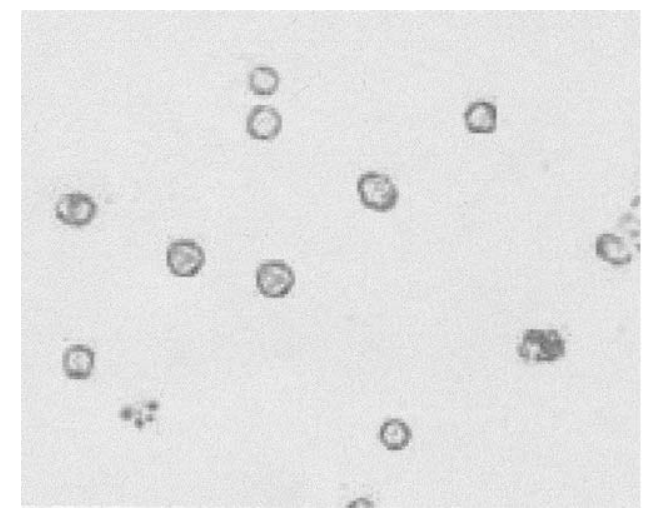

(a)

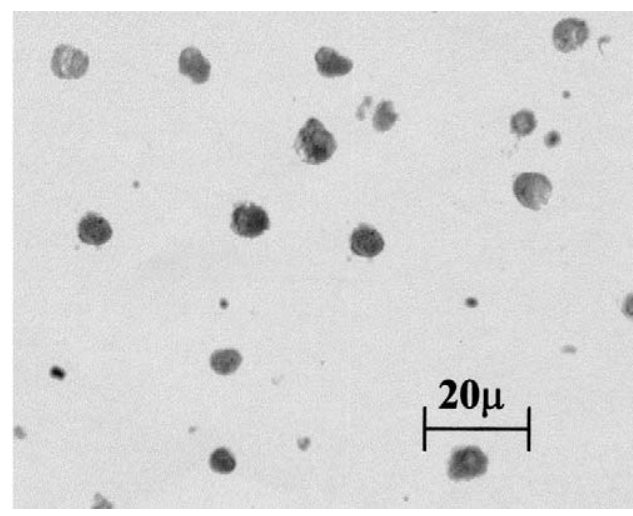

(b)

Figure 2 Purified monkey Leydig cells stained for Leydig cell marker 3 $\beta$-HSD. A drop of Leydig cells suspension in medium was allowed to air dry completely on a slide and was then stained for 3 $\beta$-HSD. The slides were mounted with $50 \%$ glycerol and visualized under a microscope. Leydig cells are identified by the dark blue staining due to reduction of Nitroblue Tetrazolium to a blue-colored formzan product by $\mathrm{NADH}$, derived by the action of

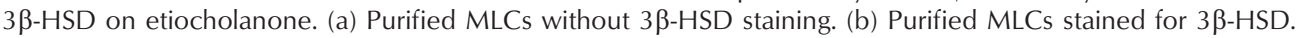




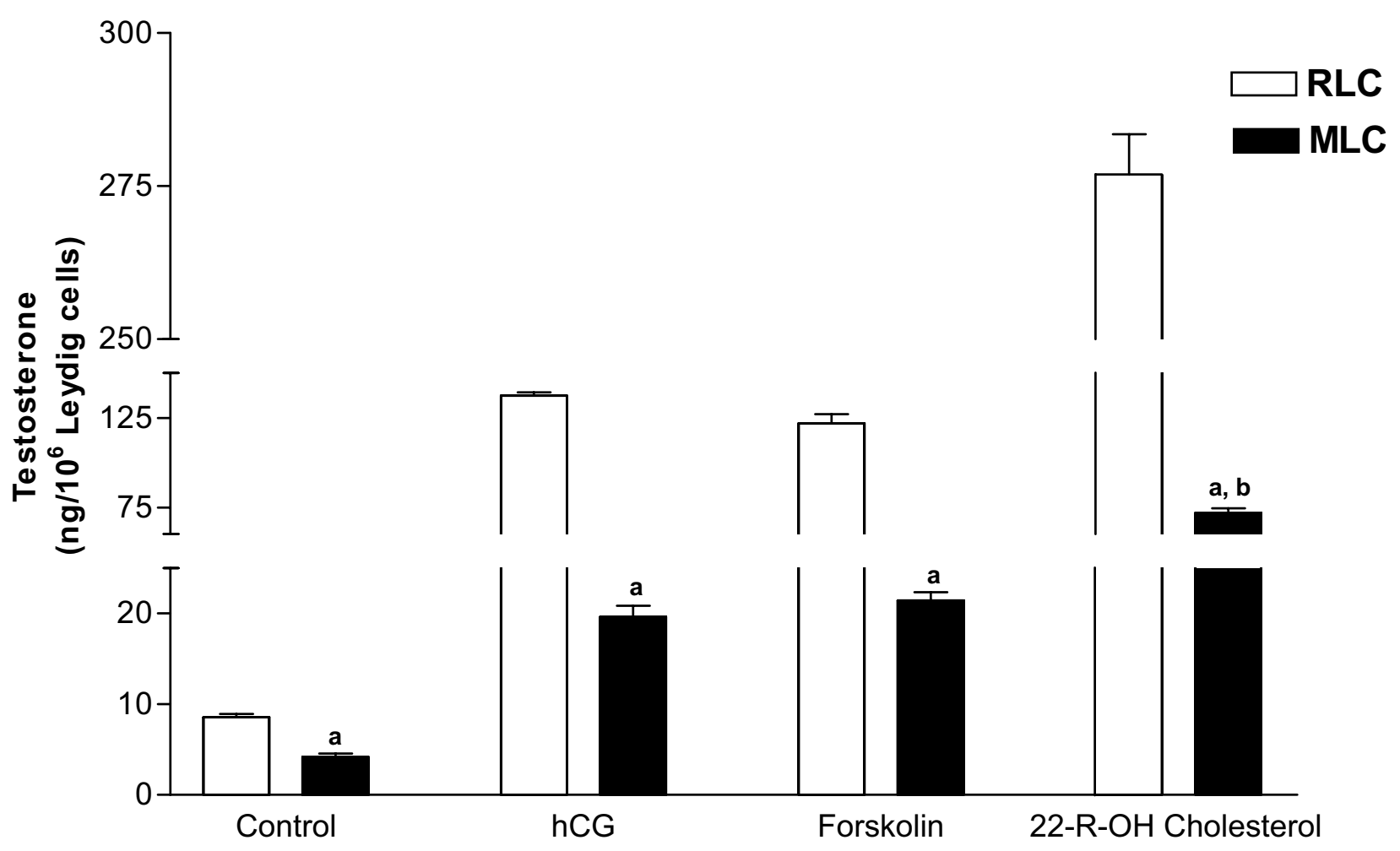

Figure 3 Graphical representation of in vitro testosterone produced by equal numbers of rat and monkey Leydig cells upon incubation with different modulators. Equal numbers of rat and monkey Leydig cells $\left(1 \times 10^{5}\right)$ were incubated with or without $100 \mathrm{ng}$ hCG, $20 \mu \mathrm{M}$ forskolin or $20 \mu \mathrm{M} 22-\mathrm{R}-\mathrm{OH}$-cholesterol in $500 \mu \mathrm{l}$ medium at $34^{\circ} \mathrm{C}$ for $4 \mathrm{~h}$ in a shaking water bath with constant agitation. The testosterone present in the medium was estimated by RIA. Values represent means \pm S.E. from three independent experiments. a, $P<0.001$ compared with the corresponding RLC values; $b, P<0.05$ compared with hCG-stimulated MLC value.

low testosterone production by MLCs in response to hCG is due to differences in the LH receptor levels and affinity of hCG to LH receptor, the effect of forskolin (which increases cAMP levels in the cell by directly activating adenylate cyclase without activation of $\mathrm{LH}$ receptor) on testosterone production by rat and monkey Leydig cells was monitored. Even in the presence of forskolin, the MLCs produced only $21.42 \pm 3.21 \mathrm{ng}$ testosterone/ $10^{6}$ cells (mean \pm S.E.) (a $5 \cdot 1$-fold increase in testosterone production over the control). Under the same conditions RLCs produced $122 \cdot 09 \pm 17 \cdot 13 \mathrm{ng}$ testosterone $/ 10^{6}$ cells (mean \pm S.E.) (a 14.6-fold increase in testosterone production over the control) (Fig. 3).

The possibility of a limitation in the availability of substrate for mitochondrial $\mathrm{P}_{450}$ side chain cleavage enzyme $\left(\mathrm{P}_{450} \mathrm{SCC}\right)$ that could account for the low testosterone-producing capacity of MLCs was studied by monitoring in vitro testosterone production by MLCs in the presence of 22-R-OH-cholesterol (a relatively hydrophilic form of cholesterol that can easily diffuse into the mitochondria). MLCs produced $71.94 \pm 8.56 \mathrm{ng}$ testosterone $/ 10^{6}$ cells (mean \pm S.E.) (a $17 \cdot 1$-fold increase in testosterone production over the control). Under the same conditions RLCs produced $276 \cdot 9 \pm 22 \cdot 84 \mathrm{ng}$ testosterone $/ 10^{6}$ cells (mean \pm S.E.) (a 33-2-fold increase in testosterone production over the control) (Fig. 3).

Comparison of smooth endoplasmic reticulum (SER) and mitochondrial content in MLCs and RLCs

The mitochondria and SER contain the enzymes necessary for the synthesis of steroid hormones. It has been well documented that the abundance of mitochondria and SER determines the steroidogenic potential of the Leydig cells (Christensen 1970, Fawcett 1981). In order to account for the low testosterone-producing capacity of MLCs, the levels of mitochondria and SER were compared between monkey and rat Leydig cells. $\operatorname{DiOC}_{6}(3)$ is a general membrane dye that can be used for staining the SER and mitochondria. The usefulness of this dye in comparing the SER content between different cells was evaluated by staining the frozen sections of rat testis with this dye. It was observed that the Leydig cells present in the interstitium emitted intense green fluorescence due to the relative abundance of SER and mitochondrial content (Fig. 4) compared with the surrounding Sertoli cells and germ cells, thus validating the use of $\mathrm{DiOC}_{6}(3)$ to compare the mitochondria and SER content between different cells. 


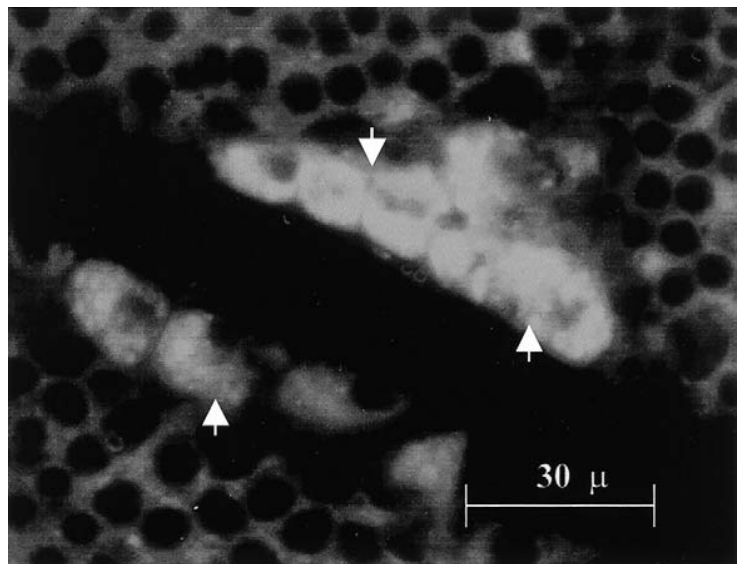

Figure 4 Fluorescent image of rat testis section stained with $\mathrm{DiOC}_{6}(3)$. Rat testis was fixed in $0.5 \%$ glutaraldehyde in $100 \mathrm{mM}$ cacodylate buffer and frozen sections were taken. The sections were stained with $\mathrm{DiOC}_{6}(3)$ and observed under a fluorescent microscope with blue light excitation and the green fluorescent image was captured. The arrows indicate the Leydig cells stained intensely in the interstitial space compared with the tubular cells present in the surrounding tubules.

Staining of monkey and rat Leydig cells with $\mathrm{DiOC}_{6}(3)$ revealed that the fluorescence emitted by the MLCs is much less compared with the RLCs (Fig. 5A) suggesting that the mitochondrial and SER content is less in the MLCs compared with that of the RLCs. Computational analysis of relative intensities of fluorescence emitted per unit area (cytoplasm) of MLCs is less $(27 \% \pm 9 \cdot 11 \%$, mean \pm S.E.) compared with the RLCs $(97 \% \pm 11 \cdot 76 \%$, mean \pm S.E.) (Fig. 5B).

\section{Discussion}

In this study a homogeneous population of Leydig cells was isolated from monkey testis and the in vitro testosteroneproducing ability of MLCs was compared with that of RLCs. Following Percoll gradient fractionation of interstitial cells, the cells recovered from fractions with densities corresponding to $1 \cdot 064-1.070 \mathrm{~g} / \mathrm{ml}$ responded maximally to in vitro addition of hCG by producing testosterone (Fig. 1), suggesting that these cells represent Leydig cell population. Under the light microscope, the Leydig cells were identified by their yellowish appearance and granular texture. Damage caused to the seminiferous tubules due to mincing of testis tissue and high concentrations of collagenase used for digestion was responsible for germ cell contamination in the MLCs purified by procedure 1 . As described in procedure 2, decreasing the concentration of collagenase and increasing the time for enzymatic digestion of testicular tissue pieces resulted in minimal germ cell and sperm contamination although the yield of Leydig cells/g tissue was compromised. It is well docu- mented that adult RLCs can be recovered from the Percoll fractions corresponding to densities $1 \cdot 070-1 \cdot 090 \mathrm{~g} / \mathrm{ml}$ (Klinefelter et al. 1987, Sriraman et al. 2000, 2003). The present observation that the adult MLCs band at a density corresponding to $1 \cdot 064-1 \cdot 070$, suggests that MLCs are less dense compared with RLCs.

The major factors that contribute to the testosteroneproducing ability of the Leydig cells are (i) the level of LH receptor on the Leydig cell membrane and the affinity of $\mathrm{LH} / \mathrm{hCG}$ to the $\mathrm{LH}$ receptor, (ii) substrate availability for the $\mathrm{P}_{450}$ SCC enzyme present in the mitochondria, and (iii) the area occupied by SER and mitochondria in the cytoplasm of Leydig cells. Since the MLCs produced less testosterone compared with RLCs in response to in vitro stimulation by hCG, studies were carried out to monitor possible differences in the above parameters between MLCs and RLCs that could account for the low steroidogenic capacity of MLCs. Comparison of testosterone produced by rat and monkey Leydig cells in the presence of forskolin revealed that the addition of forskolin to by-pass the LH activation step did not reveal any difference in testosterone production by MLCs (Fig. 3) and this rules out the possibility of the existence of differences in $\mathrm{LH}$ receptor numbers and binding affinity of $\mathrm{hCG} / \mathrm{LH}$ to $\mathrm{LH}$ receptor between the MLCs and RLCs that could account for the low steroidogenic capacity of MLCs.

It is widely accepted that the rate-limiting step in steroidogenesis in all the species studied so far is the transport of cholesterol into the mitochondria and its subsequent availability to side chain cleavage enzyme. Following incubation with hCG and forskolin, MLCs produced an average of $16.5 \%$ and $17 \cdot 7 \%$ respectively of the testosterone produced by RLCs. Interestingly, in the presence of 22-R-OH-cholesterol the MLCs produced an average of $26.8 \%$ of the testosterone produced by the RLCs (Fig. 3). This result suggests the possibility that the rate of cholesterol transport into the mitochondria is less in MLCs compared with RLCs, which partly accounts for the low testosterone-producing ability of MLCs. The observation that the fluorescence intensity emitted per unit area of MLC is less compared with the RLCs (Fig. 5B), suggests that MLCs possess low mitochondrial and SER content. However, further stereological analysis is needed to confirm this assumption. Based on these results it can be assumed that the comparatively low mitochondrial and SER content in the MLCs also accounts for the low testosterone-producing ability of the MLCs. A direct correlation in the species differences in Leydig cell testosterone production and relative levels of mitochondria and SER content in the Leydig cell has been suggested earlier (Zirkin et. al.1980).

Sex hormone binding protein or sex hormone binding globulin (SHBG), a plasma glycoprotein found in many species including humans and non-human primates, binds to androgens with very high affinity (Joseph 1994). While adult rats do not have plasma SHBG, in immature male 
A
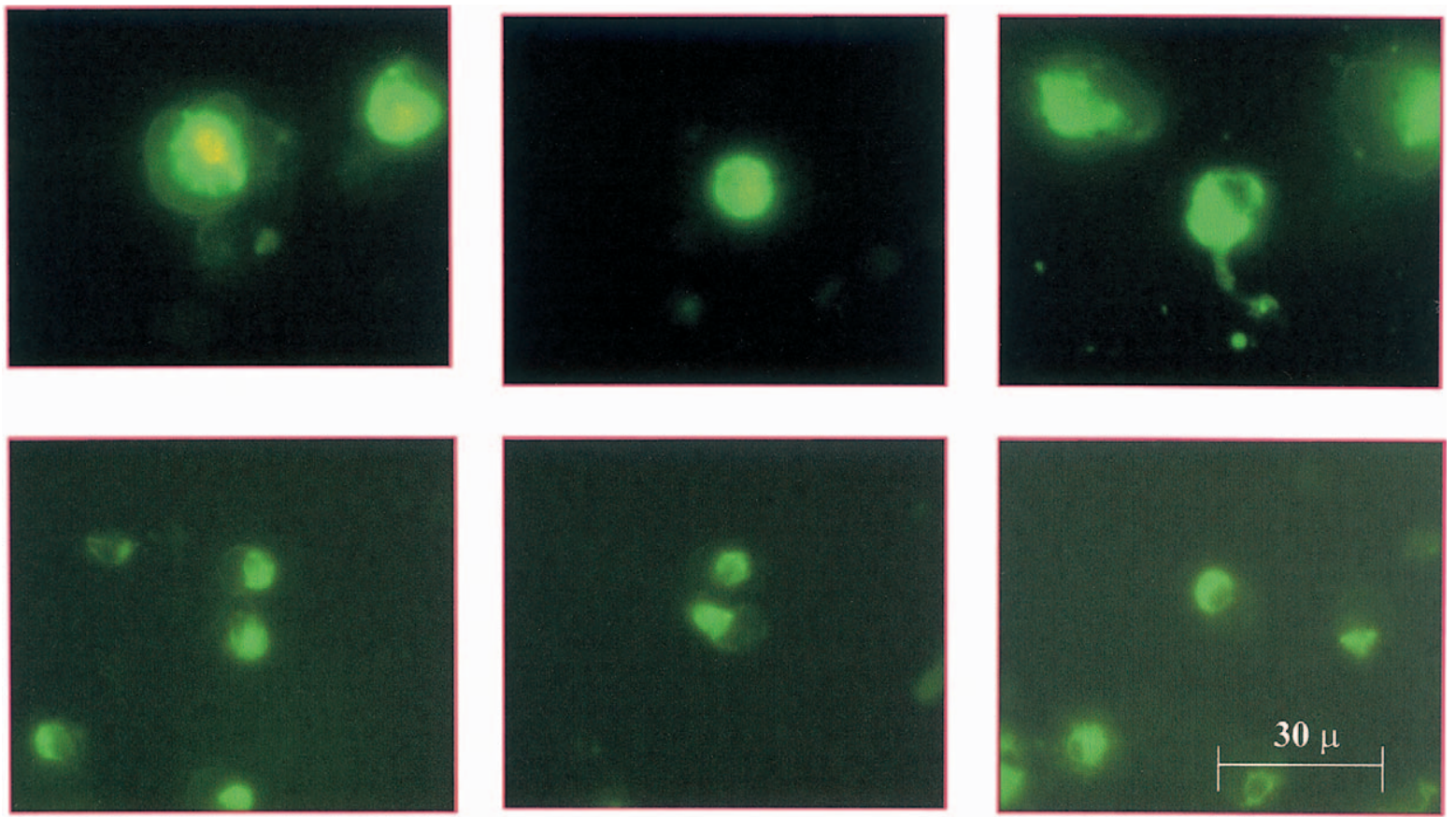

B

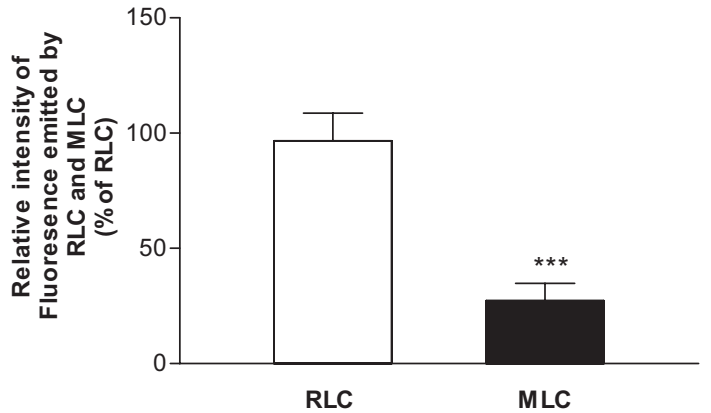

Figure 5 (A) Fluorescent image of rat and monkey Leydig cells stained with $\mathrm{DiOC}_{6}(3)$. Rat (upper panels) and monkey (lower panels) Leydig cells were allowed to attach to separate glass cover-slips by culturing them in vitro in $5 \% \mathrm{CO}_{2}$ for $4 \mathrm{~h}$. The cells attached on cover-slips were incubated in medium containing $2.5 \mu \mathrm{g} / \mathrm{ml} \mathrm{DiOC}_{6}(3)$ for $5 \mathrm{~min}$. Later, cover-slips were washed with dye-free medium, mounted on glass slides and observed under a fluorescent microscope with blue light excitation and the green fluorescent image was captured. Upper three panels, RLCs; lower three panels, MLCs. $n=3$. (B) Level of fluorescent intensities emitted by rat and monkey Leydig cells. The fluorescent images of $\operatorname{DiOC}_{6}(3)$-stained rat and monkey Leydig cells were captured by using a LEICA fluorescence microscope (Germany) and the fluorescence emitted per unit area of cytoplasm of at least 10-15 monkey and rat Leydig cells were analyzed by computer. The values represent relative intensities. ${ }^{* * *} P<0 \cdot 001$ compared with RLC.

rats, circulating androgen binding protein $(\mathrm{ABP})$ can be detected by day 15 of postnatal life; the level of this peptide peaks at day 20 and becomes negligible after day 40 (Danzo \& Eller 1985). It is pertinent to note that SHBG has been shown to be a major determinant of testosterone clearance in the primate serum (Petra et al. 1985). These observations suggest that the metabolic clearance rate of testosterone in monkeys could be less compared with the adult rats and it is possible that in order to maintain adequate testosterone levels in rats the RLCs produce more testosterone compared with the MLCs. In this connection it is pertinent to note that like MLCs, human Leydig cells also produce less testosterone compared with RLCs in response to in vitro addition of hCG (Simpson et al. 1987).

In conclusion, for the first time a highly purified population of Leydig cells has been isolated from monkey testis. Comparison of the testosterone-producing ability of MLCs and RLCs suggests that MLCs possess low steroidogenic capacity compared with RLCs. Analysis revealed that a decrease in the rate of cholesterol transport into the mitochondria and low mitochondria and SER content in MLCs are the possible reasons for the low testosterone producing capacity of the MLCs. 


\section{Acknowledgements}

The authors wish to thank Dr M P Hardy, The Population Council, New York for his valuable suggestions. Thanks are extended to Dr Frank S French, Dr Susan H Hall, Dr Peter Petrusz, and Mrs Gail Grossman, Laboratories for Reproductive Biology, University of North Carolina at Chapel Hill, USA, for helping us in work related to SER staining. The authors also wish to thank Dr S G Ramachandra, Mr V Ramesh and Mr H N Krishamurthy, Primate Research Laboratory, Indian Institute of Science, Bangalore, India, for carrying out surgery.

\section{Funding}

Financial assistance from CSIR, DBT, ICMR, (Government of India) and CONRAD, MELLON Foundation (USA) is gratefully acknowledged.

\section{References}

Christensen AK 1970 Fine structure of testicular interstitial cells in humans. In The Human Testis, pp 75-89. Eds E Rosemberg \& CA Paulsen. New York: Plenum Press.

Danzo BJ \& Eller BC 1985 The ontogeny of biologically active androgen-binding protein in rat plasma, testis, and epididymis. Endocrinology 117 1380-1388.

Fawcett DW 1981 Smooth endoplasmic reticulum. Cytoplasmic inclusions. In The Cell, pp 330-351 and 672. Philadelphia: WB Saunders.

Fawcett DW, Neaves WB \& Flores MN 1973 Comparative observations on intertubular lymphatics and the organization of the interstitial tissue of the mammalian testis. Biology of Reproduction 9 $500-532$.

Fisher JS, Millar MR, Majdic G, Saunders PT, Fraser HM \& Sharpe RM 1997 Immuno-localisation of oestrogen receptor-alpha within the testis and excurrent ducts of the rat and marmoset monkey from perinatal life to adulthood. Journal of Endocrinology 153 485-495

Joseph DR 1994 Structure, function, and regulation of androgenbinding protein/sex hormone globulin. In Vitamins and Hormones: Advances in Research and Applications, vol. 49, pp 197-280 (and references therein). Ed. G Litwack. New York: Academic Press.

Klinefelter GR, Hall, PF \& Ewing LL 1987 Effect of luteinizing hormone deprivation in situ on steroidogenesis of rat Leydig cells purified by a multi-step procedure. Biology of Reproduction $\mathbf{3 6}$ 769-783.
Mukku V, Prahalada S \& Moudgal NR 1976 Effect of constant light on nychthemeral variations in serum testosterone in male Macaca radiata. Nature $260778-780$.

Pelletier G 2000 Localization of androgen and estrogen receptors in rat and primate tissues. Histology and Histopathology 15 1261-1270.

Petra PH, Stanczyk FZ, Namkung PC, Fritz MA \& Novy MJ 1985 Direct effect of sex steroid-binding protein (SBP) of plasma on the metabolic clearance rate of testosterone in the rhesus macaque. Journal of Steroid Biochemistry 22 739-746.

Phillips HJ 1973 Dye exclusion tests for cell viability. In Tissue Culture: Methods and Applications, pp 406-408. Eds PF Kruse Jr \& MK Patterson Jr. New York: Academic Press.

Prince FP, Mann DR \& Fraser HM 1998 Blockade of the hypothalamic-pituitary-testicular axis with a GnRH antagonist in the neonatal marmoset monkey: changes in Leydig cell ultrastructure. Tissue and Cell 30 651-661.

Rey R, Campo S, Ayuso S, Nagle C \& Chemes H. 1995 Testicular steroidogenesis in the Cebus monkey throughout postnatal development. Biology of Reproduction 52 997-1002.

Rune GM, de Souza P \& Merker HJ 1991 Ultrastructural and histochemical characterization of marmoset (Callithrix jacchus) Leydig cells during postnatal development. Anatomy and Embryology 183 179-191.

Sachs BD \& Meisel RL 1988 The physiology of male sexual behaviour. In The Physiology of Reproduction, pp 1393-1485. Eds E. Knobil, J Neil, LL Ewing, GS Greenwald, CL Market \& DW Pfaff. New York: Raven Press.

Saunders PT, Sharpe RM, Williams K, Macpherson S, Urquart H, Irvine DS \& Millar MR 2001 Differential expression of oestrogen receptor alpha and beta proteins in the testes and male reproductive system of human and non-human primates. Molecular Human Reproduction 7 227-236.

Simpson BJ, Wu FC \& Sharpe RM 1987 Isolation of human Leydig cells which are highly responsive to human chorionic gonadotropin. Journal of Clinical Endocrinology and Metabolism. 65 415-422.

Sriraman V, Rao VS, Sairam MR \& Rao AJ 2000 Effect of deprival of LH on Leydig cell proliferation: involvement of PCNA, cyclin D3 and IGF-I. Molecular and Cellular Endocrinology 162 113-120.

Sriraman V, Sairam MR \& Rao AJ 2003 Evaluation of relative roles of LH and FSH in regulation of differentiation of Leydig cells using an ethane 1,2-dimethylsulfonate-treated adult rat model. Journal of Endocrinology 176 151-161.

Terasaki M 1998 Labeling of the endoplasmic reticulum with DiOC $_{6}(3)$. In Cell Biology: A Laboratory Handbook, edn 2, vol. 2, pp 501-506. Ed JE Celis. California: Academic Press.

Zirkin BR, Ewing LL, Kromann N \& Cochran RC 1980 Testosterone secretion by rat, rabbit, guinea pig, dog and hamster testes perfused in vitro: correlation with Leydig cell ultrastructure. Endocrinology 107 1867-1874.

Received 2 July 2003

Accepted 18 July 2003 